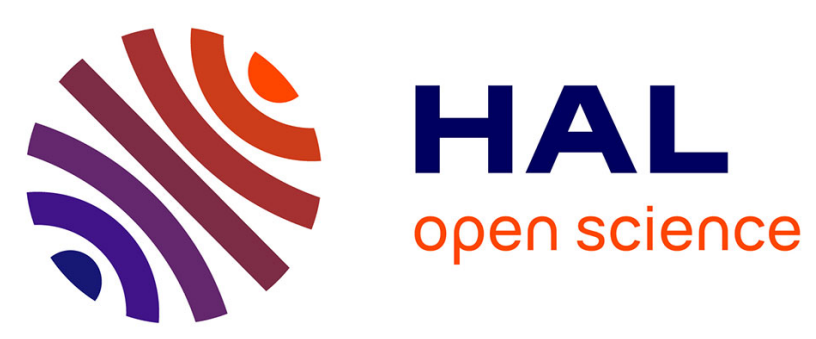

\title{
Effects of various levels of dietary triglycerides on hepatic metabolism of very low density lipoproteins in the preruminant calf, Bos spp
}

\author{
S Auboiron, Denys Durand, L Leplaix, Dominique Bauchart
}

\section{- To cite this version:}

S Auboiron, Denys Durand, L Leplaix, Dominique Bauchart. Effects of various levels of dietary triglycerides on hepatic metabolism of very low density lipoproteins in the preruminant calf, Bos spp. Annales de zootechnie, 1993, 42 (2), pp.205-205. hal-00888933

\section{HAL Id: hal-00888933 \\ https://hal.science/hal-00888933}

Submitted on 1 Jan 1993

HAL is a multi-disciplinary open access archive for the deposit and dissemination of scientific research documents, whether they are published or not. The documents may come from teaching and research institutions in France or abroad, or from public or private research centers.
L'archive ouverte pluridisciplinaire HAL, est destinée au dépôt et à la diffusion de documents scientifiques de niveau recherche, publiés ou non, émanant des établissements d'enseignement et de recherche français ou étrangers, des laboratoires publics ou privés. 


\title{
Effects of various levels of dietary triglycerides on hepatic metabolism of very low density lipoproteins in the preruminant calf, Bos spp
}

\author{
S Auboiron, D Durand, L Leplaix, D Bauchart \\ INRA, laboratoire Croissance et Métabolismes des herbivores, \\ unité de recherches Métabolismes énergétique et lipidique, \\ centre de recherches de Clermont-Ferrand/Theix, 63122 Saint-Genès-Champanelle, France
}

In bovine species, lipogenesis and secretion of triacylglycerols in very low density lipoproteins (TG-VLDL) by the liver are lower than in non-ruminant species. Consequently, at the end of gestation or beginning of lactation, when animals are in a negative energy balance, increased levels of non-esterified fatty acids (NEFA) resulting from body reserve mobilization frequently induce hepatic lipidosis. In cows, high levels of NEFA stimulate hepatic production of TG-VLDL, but not proportionally to the amounts taken up by the liver (Pullen et al, 1989). In the present study, the effects of dietary triacylglycerols (the other main source of FA for the liver) on the hepatic production of TG-VLDL in the calf have been determined.

Eleven 4-wk-old male calves $(61 \pm 12 \mathrm{~kg}$ body weight) were fitted with catheters implanted in the portal and hepatic veins and in the hepatic artery and with electromagnetic flow probes (portal vein, hepatic artery) for determination of hepatic lipoprotein fluxes. Animals were fed a conventional milk replacer in which TG was administered at levels ranging from 0.7 (from tallow) to $2.9 \mathrm{~g} / \mathrm{kg} \mathrm{BW} / \mathrm{meal}$ (from tallow plus dairy cream). Blood samples were collected at peak lipid absorption. Plasma chylomicrons ( $\mathrm{SI}>$ 400 ) and VLDL (d $<1.006 \mathrm{~g} / \mathrm{ml}$ ) were isolated by ultracentrifugal flotation and their respective chemical composition was determined by enzymatic methods.
In peripheral blood, mean plasma concentrations of TG-rich lipoproteins increased linearly $(P<0.01)$ from $2.8 \pm 2.0$ to $23.4 \pm 3.9 \mathrm{mg} / \mathrm{dl}$ for chylomicrons $(r=0.82)$ and from $3.9 \pm 3.4$ to $13.9 \pm 2.1 \mathrm{mg} / \mathrm{dl}$ for VLDL ( $r=0.78$ ) with TG intake (from 45 to $177 \mathrm{~g} /$ meal). Under these dietary conditions, hepatic balance measurements indicated constant removal of TG-chylomicrons by the liver from blood $(-0.54 \mathrm{mg} /$ $\mathrm{min} / \mathrm{kg} \mathrm{BW}$ ). Similarly, a net hepatic captation of TG-VLDL was observed $(-0.36$ to $0.28 \mathrm{mg} / \mathrm{min} / \mathrm{kg} \mathrm{BW}$ respectively) when TG intake varied from 45 to $129 \mathrm{~g} / \mathrm{meal}$. Such findings confirmed our previous results in the fasting calf and may be explained by the occurrence of lipoprotein lipase activity in the hepatic sinusoids, as demonstrated by Vilarò et al (1988) in the rat. With a higher TG intake (177 $\mathrm{g} / \mathrm{meal})$, a net hepatic production of TG-VLDL was noted $(0.03 \mathrm{mg} / \mathrm{min} / \mathrm{kg} \mathrm{BW})$ which indicated a possible stimulatory effect of dietary TG on VLDL secretion by the liver in the young bovine.

Pullen DL, Palmquist DL, Emery RS (1989) $J$ Dairy Sci 72, 49-58

Vilaro S, Ramirez I, Bengtsson-Olivecrona G, Olivecrona T, Llobera M (1988) Biochem Biophys Acta 959, 106-117 